\title{
Holistic approach to health
}

\section{Sainju NK}

Nayan Kamal Sainju, Editorial Assistant, JKMC, Kathmandu Medical College, Kathmandu, Nepal.

DOI: http://dx.doi.org/10.3126/jkmc.v7i1.20620

$\mathrm{H}$ ealth used to be focused on body's ability to function and was considered as a state of normal functioning of the body that could be disrupted occasionally by disease'. World Health Organization (WHO) linked health to well-being, in terms of "physical, mental, and social well-being and defined health as "a state of complete physical, mental and social well being, not merely the absence of disease or infirmity"2. The WHO definition of health came into light in 1946 when a radical change in definition of health was needed ${ }^{2}$. The definition given by WHO was considered very optimistic as it represented health in a wider perspective. Some people even argued that it was practically impossible to achieve a complete state of physical, mental and social well-being.

In the physical domain, a healthy organism is capable of maintaining physiological homeostasis through changing circumstances ${ }^{3}$. Hence an adaptation to the changing internal and external factors which have direct effect on physical health can be considered as the state maintenance of health. Mental health plays a crucial role in the well being of an individual. Only being in a sound mental state can't be considered as health but the ability of an individual to cope with adverse circumstances and still be able to live a meaningful and productive life is something we can consider to be a healthy state. It has been argued that a strong sense of coherence will make individuals capable of finding meaning, values and the motivation to persist in the face of adversity 4 . Social well-being is a state in which one feels that basic human needs have been met and a sense of belonging and social inclusion exists. The ability to remodel one's life according to the society's needs despite the medical condition and to be involved in social activities is being in a good state of social health.

\footnotetext{
Address for correspondence

Dr. Nayan Kamal Sainju

Editorial Assistant, JKMC

Intern Doctor, Kathmandu Medical College, Sinamangal,

Kathmandu, Nepal.

E-mail: nayansainju105@gmail.com
}

In order to be healthy, one should have a balance between physical, mental as well as social domain, which in most of the situations is challenging. It thus means that most of people are in a state of illness though they do not have any disease. So, our goal should be to move towards physical, mental and social well-being, a state that is challenging to measure. To be more realistic, the concept of well-being may seem far from the actual daily lives of the people.

A holistic approach should be adopted while conceptualizing health and well-being. Health in a broader spectrum may be taken as homeostatic mechanism of maintaining equilibrium between the external and internal factors of an individual. A person can be considered healthy as long as s/he can live a productive life within the person's social context in spite of all adverse circumstances. It is also important to have a balance between body, mind and spirit to maintain the quality of life $e^{5}$.

Holistic approach to health is an overall approach to health and well-being of the whole person, rather than focusing on illness or specific parts of the body. It takes into account of how an individual interacts with his/ her environment and emphasizes the connection between mind, body, and spirit to achieve an utmost level of wellbeing. Holistic approach will further encourage people to accept responsibility for their own health and wellbeing $^{6}$.

It is the responsibility of society and the overall structures of the government to facilitate the achievement of the goal of complete well being. For the same reason, many countries around the globe have created their health policies to achieve a desired level of health. Different societies and states have different preferences over the health care system. One may believe that modern allopathic medicine is superior to others and the rest might have strong belief on traditional healing methods like Ayurveda, Naturopathy, Unani, Siddha, Homoeopathy etc. People should have freedom of choosing a health care system of their choice within the 
healthcare delivery system of any state. Any one system should not be touted as superior to the other; rather they must go hand in hand. The WHO has launched Traditional Medicine Strategy 2014-23 to support member states to develop policies and to strengthen the role of traditional medicine in keeping populations healthy?

Complementary and alternative medicine (CAM) has become major part of the healthcare system in all advanced societies these days ${ }^{8}$ and its use has been increasing 9 . The Government of India (Gol) has launched the National AYUSH (Ayurveda, Yoga and Naturopathy, Unani, Siddha and Homoeopathy) Mission with the objective of providing cost effective AYUSH Services to its population ${ }^{10}$. Gol and other institutes throughout the world also support clinical and laboratory research on Ayurvedic medicine within the context of the eastern belief system ${ }^{11}$. Similarly, the Royal Government of Bhutan also promotes the traditional medicine system by effectively integrating it into the overall national healthcare delivery system ${ }^{12}$. Chinese medicine board of Australia has started legislation to register traditional Chinese medical practitioners in Australia and hence endorsed the system as the mainstream of health care system ${ }^{13}$.

The National health policy of Nepal 2071 has also made provisions for the complementary medicine systems in healthcare delivery in Nepal. It is stated that Ayurveda will be developed gradually and necessary reformation will be done by assessing quality of services provided in this area through research. Long term plan will be developed and implemented for the safeguard, development, and expansion of Homeopathy, Unani (Perso-Greek), and other complimentary medicine system as well ${ }^{14}$.

Many countries in the world have started providing its population with the holistic care approach. Along with the allopathic treatment, patients can have consultation of Ayurveda, Naturopathy, Yoga and meditation for the treatment of their aliments under the roof of the same healthcare centre. This system of healthcare sounds very promising to the well-being of the population. Research suggests that most people turn towards CAM therapies along with conventional medicine ${ }^{15}$. Patients expect to be treated as individuals rather than as a collection of symptoms and want an improved quality of life, selfhelp advice along with the healing of their ailments ${ }^{16}$.

When people start to experience the holistic approach to health and well-being, they begin to feel more complete, healthier and happier, hence, leading to fulfillment of the WHO definition of Health which is "a state of complete physical, mental and social well being, not merely the absence of disease or infirmity". WHO definition of health has stood the trial of time, and as well seems much more pertinent today.

\section{REFERENCES}

1. Stokes J, Noren J, Shindell S. Definition of terms and concepts applicable to clinical preventive medicine. Journal of Community Health. 1982-01-01.8(1):3341. DOI: $10.1007 /$ bf01324395.

2. WHO.Constitution of the World Health Organization. Geneva, Switzerland:World Health Organization[Int ernet];2006[Cited on February20, 2018]. Available from http://www.who.int/governance/eb/who_ constitution_en.pdf

3. Schulkin J. Allostasis, homeostasis and the cost of physiological adaptation. Washington DC: Cambridge university press; 2004.

4. Antonovsky A. Unraveling the Mystery of Health. 1st edition. San Francisco: Jossey-Bass; 1987.

5. Albrecht GL, Devlieger PJ. The disability paradox: high quality of life against all odds. Social Science \& Medicine. 1999 Apr; 48(8):977-88.

6. Schaerer N. What is holistic health and how can I achieve it?. Ivy College of Health and Well being [Internet].2015[Cited on Feb 25, 2018]. Available from: https://www.ivy.edu.au/blog/healthwellbeing/holistic-health-can-achieve/

7. World Health Organization. WHO traditional medicine strategy: 2014-23. Geneva, Switzerland: World Health Organization [Internet]; Dec 2013[Cited on Feb 20, 2018]. Available from: www. who.int/medicines/publications/traditional/trm strategy14_23/en/

8. Tovey P, Easthope G, Adams J. The mainstreaming of complementary and alternative medicine.1st edition. London. Taylor and francis group.2004.pg1

9. Frass $M$, Strassl RP, Friehs $H$, Müllner $M$, Kundi $M$, Kaye AD. Use and Acceptance of Complementary and Alternative Medicine among the General Population and Medical Personnel: A Systematic Review. Ochsner J. 2012 spring; 12(1): 45-56. PMID: 22438782

10. Press Information Bureau, Government of India, Ministry of Health and Family Welfare. National Ayush Mission (NAM). New Delhi, India: Press Information Bureau, Government of India; Dec 
2014[Cited on Feb 20, 2018]. Available from: http:// pib.nic.in/newsite/PrintRelease.aspx?relid=113941

11. Bhandari N. Is ayurveda the key to universal healthcare in India. BMJ [Internet]. 2015[Cited on Feb 25, 2018]; 350:h2879. DOI: https://doi. org/10.1136/bmj.h2879. Available from: https:// www.bmj.com/content/350/bmj.h2879

12. Ministry of Health, Bhutan. National Health Policy 2017. Bhutan: Ministry of Health, Bhutan[Internet]; 2017[Cited on Feb 10, 2018]. Available from: http://www.gnhc.gov.bt/en/wp-content/ uploads/2017/05/nationalHpolicy.pdf

13. Australian health practitioner regulation agency. Annual report2016/17. Australia: The Australian Health Practitioner Regulation Agency [internet]; 2017[Cited on Feb28, 2018]. Available from: https://www.google.com.np/search?q=AHPRA--Report---AHPRA-Annual-Report-2016-17. PDF\&rlz=1C1CHNY_enNP690NP694\&oq=AHPRA--Report---AHPRA-Annual-Report-2016-17.PDF\&aqs =chrome..69i57j69i60.1199j0j7\&sourceid=chrome \&ie $=$ UTF-8

14. Deparment of Health Service, Ministry of Health, Government of Nepal. Annual Report 2071/72. DoHS, Ministry of Health. National Health Policy2071[Internet]; 2015[Cited on feb10, 2018]. Available from: http://www.mohp.gov.np/app/ webroot/upload/files/National\%20Health $\% 20$ Policy\%202014_Eng.pdf

15. Barnett H.Complementary and alternative medicine and patient choice in primary care. Quality in Primary Care.2007. [Internet]. Cited on Feb 15, 2018. Available from: http://primarycare.imedpub.com/ complementary-and-alternative-medicine-andpatient-choice-in-primary-care.php?aid=1336

16. Richardson J. What patients expect from complementary therapy: a qualitative study. American Journal of Public Health 2004; 94:104951. 